\title{
Implementasi Pendidikan Agama Kristen di Era Teknologi
}

\author{
Arozatulo Telaumbanua \\ Sekolah Tinggi Teologi Anugerah Misi, Nias Barat \\ artel741989@gmail.com
}

\begin{abstract}
The development of this technology is a motivation for Christian Religious Education to implement technology-based learning systems. Thus the Christian religion teacher must develop the Christian Religious Education learning system based on technological developments. Changes and dynamics in the learning system, the Christian Religious Education must be taught openly through the public space that is technology based on Christian values. The author as an observer of Christian Religious Education expects the application of Christian Religious Education in the technological era to be able to bring about a change in our paradigm of the media used by God through us to proclaim the kingdom of God in this world. The application of Christian Religious Education in this technological era must be taught creatively, dynamically and effectively and with fun based on the Bible. The method used by the authors in this study is library research method, which is to conduct an analysis based on books and literature as well as previous research related to the discussion.
\end{abstract}

Keywords: implementation; Christian religious education; technological era

\begin{abstract}
Abstrak
Perkembangan teknologi ini menjadi motivasi bagi Pendidikan Agama Kristen untuk menerapkan sistem pembelajaran yang berbasis teknologi. Dengan demikian guru agama Kristen harus mengembangkan sistem pembelajaran Pendidikan Agama Kristen tersebut berdasarkan perkembangan teknologi. Terjadinya perubahan dan dinamika di dalam sistem pembelajaran, maka Pendidikan Agama Kristen harus diajarkan secara terbuka melalui ruang public yakni teknologi berdasarkan pada nilai-nilai kekristenan. Penulis sebagai pemerhati Pendidikan Agama Kristen mengharapkan penerapan Pendidikan Agama Kristen di era teknologi mampu membawa perubahan paradigma kita tentang media yang digunakan oleh Allah melalui kita untuk meproklamirkan Kerajaan Allah di dunia ini. Penerapan Pendidikan Agama Kristen di era teknologi ini harus diajarkan dengan kreatif, dinamis dan efektif serta menyenangkan berdasarkan Alkitabiah. Adapun metode yang digunakan oleh penulis dalam penelitian ini adalah metode penelitian pustaka, yakni melakukan analisis berdasarkan bukubuku dan literatur serta penelitian sebelumnya yang berkaitan dengan pembahasan.
\end{abstract}

Kata Kunci: implementasi; Pendidikan Agama Kristen; era teknologi 


\section{PENDAHULUAN}

Tulisan ini mengkaji sejauh mana implementasi Pendidikan Agama Kristen di era teknologi. Perkembangan teknologi pada saat ini meruPendidikan Agama Kristenan tantangan bagi semua orang dan guru Pendidikan Agama Kristen yang tidak mau mengikuti perkembangan teknologi yang semakin canggih tersebut. Hal ini tidak hanya berkaitan dengan proses perkembangan tetapi juga mempengaruhi kualitas pendidikan itu sendiri. Berdasarkan pengamatan penulis, sekolah Kristen yang menyelenggarakan Pendidikan Agama Kristen mengalami kendala dalam menerapkan pembelajaran Pendidikan Agama Kristen yang berbasis teknologi, diantaranya fasilitas yang kurang memadai seperti jaringan wifi. Kemudian, juga guru Pendidikan Agama Kristen kurang mahir dalam menggunakan dan mengaplikasikan pembelajaran yang berbasis teknologi.

Selain itu, siswa sebagai subjek pendidikan mengalami tantangan tersendiri, yakni tidak semua memiliki laptop atau handphone canggih yang dapat digunakan untuk melakukan pembelajaran. Juga dipengaruhi oleh

\footnotetext{
${ }^{1}$ Daniel S. Tjanda, "Impelementasi Pembelajaran Pendidikan Agama Kristen Di
}

keadaan ekonomi orang tua, sehingga penerapan pembelajaran Pendidikan Agama Kristen di era teknologi menjadi masalah. Namun demikian, penerapan pembelajaran yang berbasis teknologi mau tidak mau harus diterapkan di dalam Pendidikan Agama Kristen.

Secara umum dapat kita pahami bahwa dalam menerapkan pembelajaran Pendidikan Agama Kristen di era teknologi, ada banyak faktor yang mempengaruhi sehingga mengalami kesulitan untuk menerapkannya.

Faktor tersebut diantaranya kurangnya pengetahuan dan kemampuan mengoperasikan media teknologi. Pandangan yang salah terhadap perkembanganteknologi yang ada dan berbagai faktor sarana prasarana lainnya. Menurut Daniel S. Tjanda bahwa:

Era globalisasi tidak dapat dihindari, mau atau tidak mau siap atau tidak siap setiap orang menghadapi globalisasi. Era globalisasi dapat dikatakan sebagai era keterbukaan, era teknologi yang dekat dengan kehidupan masyarakat bahkan melekat dalamkehidupan sehari-hari. Globalisasi mewarnai dan mempengaruhi segala aspek kehidupan tanpa terkecuali ranah pendidikan mengalami atau tekena efek dari kemajuan zaman, globalisasi dan kecanggihan teknologi. ${ }^{1}$ 
Dari penjelasan di atas, Ketika guru agama Kristen tidak menerapkan system pembelajaran teknologi yang lebih dikenal dengan istilah daring (dalam jaringan), maka menjadi masalah tersendiri bagi guru dan pembelajaran Pendidikan Agama Kristen yang diharapkan diproklamirkan Injil dan Kerajaan Allah. Dapat dikatakan guru tersebut ketinggalan.

Hal inilah yang menjadi alasan penulis menuliskan karya ilmiah ini agar setiap guru agama Kristen mengerti dan memahami bahwa dalam pembelajaran yang bersifat tradisional, misalnya masih mengajar dengan sistem lama. Hal ini tidak relevan dengan kebutuhan para murid yang lahir di zaman teknologi.

Pemerintah melalui Menteri Pendidikan dan Kebudayaan terus melakukan inovasi pendidikan yang berbasis teknologi. Dalam situasi Indonesia saat ini menghadapi pandemik Corona Virus Disease (Covid-19), Pemerintah justru menerapkan secara maksimal pembelajaran dalam jaringan.

Pembelajaran "Dalam Jaringan" merupakan Pendidikan Agama Kristenan pembelajaran yang berbasis

\footnotetext{
${ }^{2}$ Surat Edaran Menteri Pendidikan Dan Kebudayaan Republik Indonesia, Nomor 36962, Hal: Pembelajaran Secara Daring Dan Bekerja Dari Rumah Dalam Rangka
}

teknologi. Dalam Surat Edaran Menteri Pendidikan dan Kebudayaan Republik Indonesia menjelaskan bahwa "pegawai, guru, dan dosen melakukan aktivitas bekerja, mengajar atau memberi kuliah dari rumah (Bekerja Dari Rumah/BDR) melalui video conference, digital dokuments, dan sarana daring lainnya."2

Menurut Undang-undang No. 20 Tahun 2003 menyebutkan bahwa sarana pembelajaran teknologi berupa "radio, audio/video, TV dan/atau berbasis jaringan computer". ${ }^{3}$ Dalam perkembangannya, saat ini pembelajaran berbasis teknologi dapat dilakukan melalui email, website, WhatsApp, Twitter, Instagram, Aplikasi Zoom dan sarana teknologi lainnya.

Implementasi teknologi dalam pembelajaran juga paralel dengan implementasi nilai Kristen. Artinya, penerapan Pendidikan Agama Kristen yang berbasis teknologi sangat penting dilakukan saat ini. Sebab kita berada pada zaman teknologi bahkan sudah sebagian besar pembelajaran dilakukan secara online. Kemudian, melalui teknologi kita memproklamirkan Injil melalui pembelajaran Pendidikan Agama Kristen

Pencegahan Penyebaran Corona Virus Disease (COVID- 19)., n.d.

${ }^{3}$ Undang-Undang No. 20 Tahun 2003 Tentang Sistem Pendidikan Nasional, Pasal 31., n.d. 
kepada semua orang melalui teknologi itu sendiri.

Arozatulo Telaumbanua menegaskan bahwa "perkembangan ilmu pengetahuan dan teknologi atau perubahan zaman, tidak menjadi alasan bagi para pendidik untuk tidak mengajarkan Pendidikan Agama Kristen dan melakukan perannya sebagai guru yang dipercayakan oleh Allah dalam mendidik dan membentuk karakter siswa." 4

Artinya, penerapan Pendidikan Agama Kristen selain menerapkan sistem pembelajaran berbasis teknologi, juga menerapkan pembelajaran yang bersifat spiritual. Implementasi pembelajaran di era teknologi mendorong siapa pun belajar mengembangkan dirinya, namun harus diperhatikan bahwa teknologi dapat membawa kepada kehancuran ketika tidak dapat diimplementasikan dengan baik. Sebab itu, implementasi pembelajaran Pendidikan Agama Kristen di era teknologi harus didasarkan pada kebenaran Allah yakni Alkitab.

${ }^{4}$ Arozatulo Telaumbanua, "Peranan Guru Pendidikan Agama Kristen Dalam Membentuk Karakter Siswa," FIDEI: Jurnal Teologi Sistematika dan Praktika 1, no. 2 (n.d.): 219-231.

${ }^{5}$ Sarwono, Metode Riset Bidang Desain (Yogayakrta: Andi Offset, 2007).
Penelitian ini bertujuan untuk menjelaskan bahwa betapa pentingnya diterapkan pembelajaran Pendidikan Agama Kristen yang berbasis teknologi. Juga peran guru agama Kristen dalam menerapkan pembelajaran yang berbasis teknologi sangat penting. Dalam hal ini penulis menguraikan dua variabel yakni implementasi Pendidikan Agama Kristen dan pembelajaran Era Teknologi.

\section{METODE PENELITIAN}

Metode yang digunakan dalam penelitian ini adalah metode penelitian pustaka. Menurut Sarwono, penelitian pustaka adalah "mempelajari berbagai buku referensi serta hasil penelitian sebelumnya yang sejenis yang berguna untuk mendapatkan landasan teori mengenai masalah yang akan diteliti." ${ }^{5}$ Metode pustaka yaitu membaca buku-buku, menyelidiki kitab yang berkaitan dengan pokok bahasan karya ilmiah ini." etelah dianalisis maka dituangkan di dalam hasil dan pembahasan berdasarkan hasil tersebut maka dibuatlah satu kesimpulan yang menjadi harapan dan tujuan penelitian ini.

\footnotetext{
${ }^{6}$ Asni Darmayanti Duha, "Etika
} BerPendidikan Agama Kristen Bagi Kaum Perempuan Dalam Ibadah Menurut I Timotius 2:910 Dan Aplikasinya Masa Kini," Jurnal TeologiBerita Hidup 2, no. 2 (Maret 2020.): 154 170. 


\section{HASIL DAN PEMBAHASAN}

Setelah peneliti menjelaskan tentang pokok persoalan di latar belakang maka dalam bagian ini, penulis akan menguraikan secara teoritis tentang Pendidikan Agama Kristen dan Implementasi Pendidikan Agama Kristen di era teknologi.

\section{Pendidikan Agama Kristen}

Pendidikan Agama Kristen merupakan bagian terpenting dari pendidikan Kristen, artinya Pendidikan Agama Kristen merupakan kelanjutan dari Pendidikan Kristen, oleh sebab itu Pendidikan Kristen harus mengacu kepada proses pembelajaran secara umum dalam kekristenan sedangkan Pendidikan Agama Kristen lebih kepada pengkhususan kepada proses pembelajaran itu sendiri.

Makna kata Kristen dalam istilah Pendidikan Agama Kristen merupakan pendidikan agama yang dilakukan oleh persekutuan iman Kristen (orang Kristen) dari perspektif agama Kristen dan nilai-nila Kristen. Robert $\mathrm{R}$. Boehlke mengutip asumsi John Calvin yang mengatakan memupuk

\footnotetext{
${ }^{7}$ Robeth R. Boehlke, Sejarah PerkembanganPikiran Dan Praktek PAK (Jakarta: BPK GunungMulia, 2005).
}

segala pengetahuan, akal dan pikiran bagi orang percaya, yakni:

Pendidikan Agama Kristen adalah pemumpuk akal orang-orang percaya dan anak mereka dengan Firman Allah dibawah bimbingan Roh Kudus melalui sejumlah pengalaman belajar yang dilakukan gereja, sehingga dalam diri mereka dihasilkan pertumbuhan rohani yang bersinambungan yang diejawantahkan semakin mendalami melalui pengabdian diri kepada Allah Bapa Tuhan Yesus Kristus berupa tindakan-tindakan kasih terhadap sesamanya. ${ }^{7}$

Pendidikan Agama Kristen harus menghasilkan pertumbuhan rohani bagi setiap pribadi yang sedang belajar Pendidikan Agama Kristen tersebut. E. G. Homrighausen dan I. H. Enklaar mengatakan Pendidikan Agama Kristen mencakup segala usia, baik tua maupun muda bahkan anak-anak dalam persekutuan iman yang kemudian dinyatakan dalam persekutuan bersama, sebagai berikut:

Inilah arti yang sedalam-dalamnya dari Pendidikan Agama Kristen, bahwa dengan menerima pendidikan itu, segala pelajar, muda dan tua, memasuki persekutuan iman yang hidup dengan Tuhan sendiri, dan oleh dan dalam Dia mereka terhisab pula pada persekutuan jemaatnya yang mengakui dan mempermuliakan namaNya dan segala waktu dan tempat. ${ }^{8}$

\footnotetext{
${ }^{8}$ E. G. Homrighausen dan I. H. Enklaar, Pendidikan Agama Kristen (Jakarta: BPK GunungMulia, 2004).
} 
Berdasarkan beberapa defenisi di atas, maka Pendidikan Agama Kristen sebagai proses pendidikan yang merupakan usaha dasar oleh pengajar yang ditujukan kepada anak didik dalam proses pembelajar yang berisikan ajaranajaran, nilai-nilai kekristenan serta penekanannya kepada ketiga aspek pendidikan yaitu: kognitif (pengetahuan), afektif (sikap), psikomotor (skill dan keterampilan), dari kesemuannya berlandaskan kepada kebenaran Firman Tuhan (Alkitabiah) atau berdasarkan kepada iman Kristen.

Rasul Paulus mengidentikkan Pendidikan Agama Kristen sebagai proses pendewasaan dan peneguhan iman (Kolose 2:6-7).

\section{Tujuan Pendidikan Agama Kristen}

Pada dasarnya, Pendidikan Agama Kristen bertujuan untuk mengajar, mengajak dan menolong seseorang atau peserta didik untuk melihat dan mengenal kasih Allah melalui Yesus Kristus. Robert R. Boehlke mengatakan bahwa:

\footnotetext{
${ }^{9}$ Robert R. Boehlik, Sejarah Perkembangan Pikiran Dan Praktek Pendidikan Agama Kristen (Jakarta: BPK Gunung Mulia, 2005).

${ }^{10}$ Paulus Lilik Kristianto, Prinsip Dan Praktek Pendidikan Agama Kristen (Yogayakrta: Andi Offset, 2008).
}

Tujuan Pendidikan Agama Kristen ialah menolong orang-orang menjadi sadar akan penyingkapan diri Allah dan kasih-Nya dalam Yesus Kristus yang senantiasa mencari orang serta menjawabnya dengan kepercayaan dan kasih, agar mereka mengetahui siapa dirinya sebenarnya, dan apa arti keadaannya, bertumbuh sebagai anakanak Allah yang berakar dalam persekutuan Kristen, memenuhi panggilannya bersama sebagai muridmurid Yesus di dunia dan tetap percaya pada pengharapan Kristen. ${ }^{9}$

Dalam tujuan Pendidikan Agama Kristen ini, setiap orang diharuskan dapat mencapai tujuan tersebut yaitu bertumbuh dalam iman dan kasih. Sebagaimana Paulus Lilik Kristianto mengatakan bahwa "tujuan Pendidikan Agama Kristen adalah memampukan orang untuk menyadari kasih Allah, yang dinyatakan dalam Yesus Kristus dan menyadari kasih tersebut melalui iman dan sarana yang akan menolong mereka bertumbuh". ${ }^{10}$

"Dan yang juga utamanya bagi Guru PAK adalah memiliki mandat Kristus untuk mendidik peserta didik dalam pengajaran yang benar menuju keterhubungan dengan Kristus dan ajaran-Nya."11

Dengan demikian, dapat disimpulkan bahwa tujuan PAK di era

\footnotetext{
${ }^{11}$ Jakob Messakh, "Korelasi Kompetensi Guru PAK SMA Negeri Se-Jakarta Dengan Identitas Sebagai Hamba Tuhan," SIKIP: Jurnal PendidikanAgama Kristen Vol. 1, No (n.d.): 47-59.
} 
teknologi adalah menanamkan nilai

Kristus kepada murid.

\section{Metode-Metode Pendidikan Agama Kristen}

Berbicara mengenai metode Pendidikan Agama Kristen, maka akan melihat perkembangan-perkembangan yang ada sehingga seorang guru mampu mengimplementasikan Pendidikan Agama Kristen dengan baik dan benar. John M. Nainggolan mengatakan

"Banyak para guru dan pengajar Kristen yang dapat memberikan pengajaran dengan baik, tetapi tidak sesuai dengan situasi dan kondisi yang sedang dihadapi dan itu mengakibatkan hasil yang tidak maksimal.""12

Dalam melaksanakan Pendidikan Agama Kristen di dunia modern, kita dapat menggunakan metode-metode seperti: ceramah, bercerita, panel, tanyajawab, diskusi dan lain-lain. Namun, dalam pelaksanaan metode tesebut harus sesuai dengan kebutuhan siswa (situasi dan kondisi), kemudian dikembangkan metode-metode tersebut sesuai dengan kreatif, inovatif yang dilakukan.

\section{Implementasi Pendidikan Agama Kristen di Era Teknologi}

Belajar Pendidikan Agama Kristen di Era Teknologi

Belajar di era modern ini memang bukan hal yang mudah dilakukan oleh seorang pengajar (guru). Sebab era modern memang menuntut adanya inovasi pendidikan termasuk pengajaran Pendidikan Agama Kristen (PAK) yang memiliki perspektif global di sekolah maupun pengajaran iman di gereja. Teknologi merupakan aspek yang merubah media penyampaikan materi pembelajaran PAK. Menurut Daniel S. Tjanda, era teknologi adalah kompleksitas teknologi pembelajaran dan munculnya gerakan restrukturasi kooperatif yang menekankan kombinasi kualitas teknologi dan manusia, menyebabkan dunia kerja akan menerima orang yang dapat mengambil inisiatif, berpikir kritis, kreatif dan cakap memecahkanmasalah". ${ }^{13}$

$$
\text { Artinya, siapa saja yang }
$$

tidak mampu mengimplementasikan atau menyesuaikan dengan perkembangan yang

\footnotetext{
13 "Impelementasi Pembelajaran Pendidikan Agama Kristen Di Abad 21," SIKIP: Jurnal Pendidikan Agama Kristen Vol. 1, No (n.d.): $1-10$.
} 
ada, maka mengalami ketinggalan bahkan sendirinya akan tersingkir. Mengajarkan Pendidikan Agama Kristen tidak sekedar teori dan memakai metode yang ada. Perlu adanya penyesuaian antara teori dengan metode dan kebutuhan.

Bahkan bukan hanya itu saja, seorang guru dituntut kreatif, dan inovatif dalam melaksanakan Pendidikan Agama Kristen itu sendiri. Meskipun kita memiliki banyak pengetahuan dan pengalaman namun jika kita tidak kreatif dan inovatif dalam pengajaran, jangan berharap kita melakukannya dengan maksimal. Menurut Alvin Toffler sebagaimana dikutip oleh Dien Sumiyatiningsih bahwa:

Sekarang kita hidup dalam era informasi. Selain wajah globalisasi yang menampilkan kecanggihan tekonologi informasi dan transportasi, di sisi lain juga tampil fenomena yang keras berupa berbagai tantangan yang perlu kita hadapi, termasuk tantangan bagi gereja. Tantangan tersebut: dunia menjadi satu kesatuan ekonomis; semakin banyak negara yang tersisih secara sosial dan ekonomis; bidang informasi berkembang pesat, bahkan terjadi lonjakan informasi; timbul moralitas yang kacau; dan kekristenan yang cenderung melemah. ${ }^{14}$

Oleh karena itu, tujuan Pendidikan Agama Kristen tidak akan tercapai jika hanya teori dan menggunakan metode yang ada tanpa ada kreatif dan inovatif di dalamnya, termasuk perubahan hidup pendidik, dalam hal ini guru. Jangan sekalikali kita memiliki perspektif yang salah dan tidak benar, bahwa yang penting materi pelajaran selesai. Selesainya materi pelajaran belum tentu tujuan Pendidikan Agama Kristen tercapai.

Sebaliknya, jika tujuan Pendidikan Agama Kristen itu tercapai secara efektif dan maksimal, maka materi yang ada di dalam Pendidikan Agama Kristen itu sudah pasti selesai.

Kreatif Dalam Implementasi

Teknologi Pendidikan Agama Kristen

Dalam menerapkan Pendidikan Agama Kristen di era teknologi, dapat dilakukan secara kreatif melalui e-mail, WhatsApp, website, video conference, media cetak dan jejaring sosial serta media teknologi cetak. Namun, media tersebut tidak akan pernah hidup jika seorang pendidik tidak kreatif dan melakukan inovatif dalam pengajarannya. Media pembelajaran yang

\footnotetext{
${ }^{14}$ Dien Sumiyatiningsih, Mengajar Dengan Kreatif \& Menarik (Yogayakrta: Andi Offset, 2012).
} 
ada kita gunakan sekreatif mungkin untuk diaplikasikan dalam pengajaran Pendidikan Agama Kristen.

"Menghadapi berbagai
perubahan individual maupun
sosial tersebut, banyak
lingkungan pendidikan Kristen,
yaitu keluarga, gereja, sekolah,
juga mengalami krisis dan
kebingunan untuk menemukan
pedoman dalam berjalan ke masa
depan berdasarkan perspektif dan
nilai-nilai Kristiani."

Karena itu, seorang guru harus kreatif dan inovatif dengan memperhatikan prinsip-prinsip berikut, yaitu pendidik memiliki pribadi yang baik dan mantap (1 Timotius 3:1-13); pendidik menjadi teladan bagi peserta didiknya (1 Timotius 4:16); pendidik menjadi komunikator kebenaran (1 Petrus 5:3); dan mengenali tanda-tanda zaman.

$$
\text { Dalam konteks ini, }
$$
pengembangan kreatif dan inovatif implementasi Pendidikan Agama Kristen di era teknologi, seorang guru harus memiliki hati seorang murid yang mau dibentuk dan bimbing oleh Roh Kudus. Artinya, seorang pendidik jangan menganggap diri hebat dalam melaksanakan Pendidikan Agama Kristen. Implementasi Pendidikan Agama Kristen di era teknologi tidak diukur secara mutlak oleh intelektual tanpa karakter Kristus di dalam dirinya.

\section{Implementasi Pendidikan Agama}

\section{Kristen di Era Teknologi}

Implementasi Pendidikan Agama Kristen di era modern ini sesungguhnya mengalami kemudahan dalam menyampaikan materi pembelajaran. Sebab itu guru harus dituntut untuk mampu menggunakan teknologi tersebut secara maksimal. Mungkin seorang guru pintar, pelaksanaannya juga baik, namun di sisi lain jika tidak kreatif dan melakukan inovatif dalam pengajarannya maka akan menjadi masalah.

Setiap model pembelajaran di era teknologi dapat diterapkan dalam materi pembelajaran Pendidikan Agama Kristen yang dilakukan dengan salah satu atau model discovery learning, di mana pendidik dapat menuntun peserta didik

untuk menemukah hal-hal baru. Menerapkan sistem pembelajaran di era teknologi berpusat pada murid bukan kepada guru.

Namun, ada beberapa hal yang harus kita perhatikan jika menerapkan Pendidikan Agama Kristen dengan baik, kreatif dan inovatif di era teknologi, yaitu: 
Penerapan Domain Desain

Pembelajaran

Di era teknologi ini telah membuka mata kita bagaimana merencanakan pembelajaran Pendidikan Agama Kristen dengan baik, menarik dan mudah dimengerti oleh siswa. Seorang guru harus berusaha mendesain pembelajaran dengan baik, sehingga materi pembelajaran PAK tersebut dapat diterima oleh siswa dengan baik pula.

Dalam Webinar Nasional yang diselenggarakan oleh Sekolah Tinggi Teologi Real Batam, Erni Murniati sebagai pembicara mengatakan dalam materinya bahwa "guru dan dosen dapat membuat materi pelajaran, menyediakan materi pelengkap, seperti sarana storytelling untuk peserta didik." 16

Perencanaan pembelajaran di era teknologi diharuskan seorang guru mampu menggunakan teknologi yang ada seperti laptop atau komputer, mampu mengoperasikan media pembelajaran dalam jaringan atau $e$ learning, misalnya e-mail, sway, OneDrive, Teams, power point, word, exel, grafik, website dan perangkat pembelajaran lainnya. Dengan desain pembelajaran seperti ini, maka pengaruhnya terhadap respon siswa sangat signifikan.

Penerapan Domain Pengembangan Pembelajaran

Dasar utama domain pengembangan pembelajaran Pendidikan Agama Kristen adalah bidang produksi media. Domain pengembangan meliputi teknologi cetak, teknologi audio visual, teknologi komputer, teknologi terpadu.

Pengembangan domain ini, seorang guru mampu menggunakan kreativitas menciptakan media pembelajaran lain yang berbeda antara media pembelajaran yang suda ada. Artinya, domain media teknologi yang sudah ada guru dapat mengembangkannya berdasarkan situasi dan ketubuhan siswa itu sendiri.

\section{Penerapan Domain Penggunaan Media Teknologi}

Pembelajaran dari tahun ke tahun mengalami perubahan yang cukup signifikan. Selama bertahun-tahun domain penggunaan media dipusatkan pada kegiatan guru dan ahli media. Penggunaan media teknologi mengacu pada sistematik, penyebaran, difusi, implementasi dan instruksionalisasi. 
Fungsi penggunaan media teknologi dalam pembelajaran Pendidikan Agama Kristen menggambarkan interfrase antara pembelajar dan sistem instruksional atau tujuan yang hendak dicapai sebagai standar kompetensi. Ada empat sub kategori dalam penggunaan media teknologi pembelajaran Pendidikan Agama Kristen yaitu difusi inovasi, implementasi, kebijakan dan peraturanperaturan.

\section{Guru Pendidikan Agama}

Kristen harus menerapkan

pembelajaran Pendidikan Agama Kristen tersebut dengan berbasis teknologi. Erni Murniati menjelaskan bahwa strategi pendidik dalam menggunakan media teknologi adalah:

Pertama: Pemilihan dan pemanfaatan media pembalajaran (teknologi) tepat.

Kedua: Penguasaan pengoperasian media.

Ketiga: Pembelajaran yang kreatif dan menyenangkan.

Keempat: Komunikasi yang efektif.

Kelima: Manajemen waktu. ${ }^{17}$

Utilisasi atau aksi dari penggunaan media teknologi dalam proses pembelajaran dan sumber belajar merupakan hal yang sangat penting dalam mencapai tujuan pendidikan. Semua situasi ini digunakan untuk mencari materi serta kegiatan yang spesifik, mempersiapkan pembelajar untuk saling berinteraksi, menyediakan bimbingan selama proses pembelajaran, mencapai hasil serta penggunaan prosedur dan organisasi pembelajaran yang tepat dan berguna bagi siswa.

Media teknologi merupakan salah satu sumber belajar. Artinya, sumber pembelajaran tidak selalu harus guru. Tetapi dapat berupa orang sumber (human resource). Oleh karenanya, guru Pendidikan Agama Kristen menerapkan domain media teknologi dengan baik.

Penerapan Domain Manajemen Teknologi Dalam PAK

Salah satu peran dan tugas guru Pendidikan Agama Kristen adalah manajer. Guru Pendidikan Agama Kristen sebagai manajer dalam pengelolaan proses pembelajaran, dituntut agar dapat mengelola proses pembelajaran dengan baik dan dengan metode pembelajaran yang terbarukan, sehingga pembelajar mengalami belajar sebagai suatu pengalaman yang menarik. Dengan demikian, memahami hal-hal baru yang

\footnotetext{
${ }^{17}$ Murniati, “"Microsoft Office Sebagai Penunjang Pembelajaran Daring.,"
} 
sebelumnya tidak dikenal dan tidak dipahaminya.

Pada domain ini teknologi sangat membantu memajemenkan proses pembelajaran dan kelas. Jangan sampai teknologi yang mengatur proses pembelajaran, tetapi guru harus mengendalikan teknologi yang digunakan dalam proses pembelajaran Pendidikan Agama Kristen. Pada dasarnya domain manajemen menjalankan fungsi manajemen dalam organisasi manajemen dan personal manajemen. Manajemen merupakan kontrol teknologi pembelajaran melalui perencanaan (planing), organisasi (organizing), koordinasi (koordinating), dan supervisi (supervising).

\section{Penerapan Domain Evaluasi \\ Pembelajaran}

Evaluasi dalam pendidikan berarti untuk menentukan kualiatas, efektifitas atau nilai dari sebuah program, hasil, proyek, proses, objektif, dan kurikulum. Dalam melaksanakan kegiatan evaluasi PAK, penting untuk mempertimbangkan :

Pertama, Standar penilaian dalam menentukan kualitas.

Kedua, Pengumpulan informasiinformasi yang relevan.
Ketiga, Penggunaan standar-standar penilaian untuk menentukan kualitas.

Dalam evaluasi, praktek teknologi terhadap skor yang dicapai pembelajar adalah sangat penting, itulah sebabnya penilaian harus dilakukan dengan adil dan benar, dan sistematis. Selain penilaian hasil belajar yang diindikasikan dengan skorskor yang dicapai, penilaian terhadap proses juga harus menjadi hal yang harus dicermati oleh guru Pendidikan Agama Kristen.

Penerapan Domain Pembelajaran Dalam Jaringan

Diterbitkannya surat Edaran Mendikbud Nomor 4 tahun 2020 tentang Pelaksanaan Kebijakan Pendidikan dalam Masa Darurat Penyebaran Covid-19, mengharuskan proses belajar mengajar dilakukan melalui jarak jauh atau dalam jaringan (daring). Guru di tuntut untuk siap menjalankan kebijakan pemerintah dalam melayani siswa belajar daring. Bukan hanya menyampaikan pelajaran sesuai kompetensi yang direncanakan, namun guru wajib memberikan pengalaman belajar bermakna bagi siswa.

Dunia digital diakui. Tepat dan bernilai. Namun, dibalik pembelajaran daring yang dilakukan oleh setiap unit satuan pendidikan, tidak luput harus memperhatikan fasilitas belajar yang 
mendukung berjalannya proses pembelajaran Pendidikan Agama

\section{Media Audio-Visual}

Kristen. Salah satunya adalah perangkat komputer maupun akses internet.

Penerapan Pendidikan Agama Kristen di era teknologi ini dapat dilakukan dengan berbagai cara. Pembelajaran dalam jaringan (daring) merupakan salah satu cara menerpakan PAK di era teknologi. Penerapan ini harus didukung oleh perangkat pembelajaran dalam jaringan (daring).

\section{Media Cetak}

Teknologi Cetak adalah cara untuk memproduksi atau menyampaikan bahan seperti buku-buku, bahan-bahan visual yang statis atau melakukan percetakan, terutama melalui pencetakan mekanis atau photografis.

Teknologi ini menjadi dasar untuk pengembangan dan pemanfaatan dari kebanyakan bahan pembelajaran lain. Hasil teknologi ini berupa cetakan.Teks dalam penampilan komputer adalah suatu contoh penggunaan teknologi komputer untuk produksi. Apabila teks tersebut dicetak dalam bentuk "cetakan" guna keperluan pembelajaran merupakan contoh penyampaian dalam bentuk teknologi cetak.

\section{Media Berbasis Komputer}

Saat ini teknologi komputer tidak lagi hanya digunakan sebagai sarana komputasi dan pengolahan kata (word processor) tetapi juga sebagai saranabelajar multi media yang memungkinkan peserta didik membuat desain dan rekayasa suatu konsep dan ilmu pengetahuan.

\section{Penggunaan Power Point}

Multimedia presentasi digunakan untuk menjelaskan materi-materi yang sifatnya teoritis, digunakan dalam pembelajaran klasikal dengan group belajar yang cukup banyak di atas 50 orang. Media ini cukup efektif sebab menggunakan 
multimedia projector yang memiliki jangkauan pancar cukup besar.

Menurut Ade Kusmana "e-learning Kelebihan media ini adalah menggabungkan semua unsur media seperti teks, video, animasi, image, grafik dan sound menjadi satu kesatuan penyajian, sehingga mengakomodasi sesuai dengan modalitas belajar siswa.

\section{Internet dan Website}

Pemanfaatan internet sebagai media pembelajaran mengkondisikan siswa untuk belajar secara mandiri. Penggunaan website tidak hanya dapat memberikan kontribusi yang positif terhadap kegiatan akademik siswa tapi juga bagi guru. Nur Rofikoh mengatakan "internet juga memberikan materi pembelajaran tanpa batas pada penggunanya. Peserta didik dapat belajar hal- hal baru yang tidak mereka dapatkan di sekolah formal. Karena apa yang diajarkan di sekolah sangat terbatas, sehingga sebagai peserta didik, dituntut bisa mandiri untuk mencari informasi tambahan di luar lingkungan pendidikan formal". ${ }^{18}$

\section{E-Learning}

${ }^{18}$ Nur Rofikoh, "Pengaruh Internet Terhadap Aktivitas Pendidikan," Jurnal Ilmiah (n.d.).

${ }^{19}$ Ade Kusmana, "E-Learning Dalam Pembelajaran," LENTERA PENDIDIKAN Vol. 14, $\mathrm{N}$ (n.d.): 35-51. memungkinkankan dua pihak atau lebih di lokasi berbeda dapat berinteraksi melalui pengiriman dua arah audio dan video secara bersamaan. Menurut Mohammad Fazrie “jumlah penggunaan video conference di dunia semakin berkembang, dengan tingginya penggunaan video conference semakin tinggi pula aspek-aspek yang diperhatikan, diantaranya aspek merupakan suatu teknologi informasi yang
relative baru di Indonesia. E-learning terdiri dua bagian yaitu " $e$ " yang merupakan singkatan dari "electronic" dan “learning” yang berarti pembelajaran. Jadi, e-learning berarti pembelajaran dengan menggunakan menggunakan jasa bantuan perangkat elektronia, khususnya perangkat komputer". 19 dalam Pendidikan Agama Kristen. Dengan itu, Pendidikan Agama Kristen mampu mencapai tujuan yang dikehendaki oleh Tuhan Yesus bagi umat-Nya.

\section{Video Converence}

Konferensi video adalah seperangkat teknologi telekomunikasi interaktif yang

E-learnig sangat efektif diterapkan 
kenyamanan dan keamanan. Berbicara tentang aspek kenyamanan pada video conference tidak lepas dari kompresi yang digunakan, baik kompresi audio dan video". ${ }^{20}$ Artinya, penggunaan video converence dalam pembelajaran Pendidikan Agama Kristen sangat efektif.

\section{KESIMPULAN DAN SARAN}

Berdasarkan kajian dan data empiris yang telah dituangkan dalam tulisan ini, penulis menemukan bahwa implementasi Pendidikan Agama Kristen di era teknologi oleh perguruan tinggi dan tenaga pendidik Kristen masih sangat kurang. Hal ini dipengaruhi oleh kurang keterampilan menerapkannya. Namun demikian, implementasi Pendidikan Agama Kristen di era teknologi harus dilakukan secara bertahap demi tercapainya tujuan Pendidikan Agama Kristen.

Dapat disimpulkan bahwa teknologi sangat mendukung kegiatan akademik dan pembelajaran dalam mencapai tujuan pendidikan secara maksimal. Penggunaan teknologi dalam pembelajaran dapat dilakukan melalui perangkat dalam jaringan (daring),

\footnotetext{
${ }^{20}$ Mohammad Fazrie, "Analisis Performansi Video Conference Menggunakan Codec H264 Baseline Dan H264-High Profile
}

seperti email, website, $W A$, dan perangkat lainnya. Dalam menggunakan teknologi kita harus kreatif melakukannya, jangan menoton dalam metode tersebut tetapi akan kita kembangkan sesuai dengan perkembangan zaman yang ada dan kebutuhan siswa.

Dengan memahami peran penting teknologi dalam Pendidikan Agama Kristen, maka proses pembelajaran saat ini dapat dilaksanakan dengan baik.

Penulis menyampaikan saran kepada kita semua khususnya agar kita belajar terus menerus, belajar teknologi dengan maksimal sehingga mampu menerapkan dalam pembelajaran kita di kelas. Dari semua yang telah dijelaskan di atas, penulis menyampaikan bahwa pembelajaran kita harus di dasarkan pada Alkitab dan nilainilai Kristus.

\footnotetext{
Dengan Enkripsi Terintegrasi,” IncomTech, Jurnal Telekomunikasidan Komputer Vol. 7, No (n.d.): 315-328.
} 


\section{DAFTAR PUSTAKA}

Boehlik, Robert R. Sejarah

PerkembanganPikiran Dan

Praktek Pendidikan Agama

Kristen. Jakarta: BPK

GunungMulia, 2005.

Boehlke, Robeth R. Sejarah

PerkembanganPikiran Dan

Praktek PAK. Jakarta: BPK

GunungMulia, 2005.

Duha, Asni Darmayanti. "Etika BerPendidikan Agama Kristen Bagi Kaum Perempuan Dalam Ibadah Menurut I Timotius 2:9-10 Dan Aplikasinya Masa Kini." Jurnal TeologiBerita Hidup 2, no. 2 (2020).

E. G. Homrighausen dan I. H. Enklaar. Pendidikan Agama Kristen. Jakarta: BPK GunungMulia, 2004.

Fazrie, Mohammad. "Analisis Performansi Video Conference Menggunakan Codec H264 Baseline Dan H264-High Profile Dengan Enkripsi Terintegrasi." IncomTech, Jurnal

Telekomunikasidan Komputer Vol. 7, No (n.d.): 315-328.

John M. Nainggolan. Guru Agama Kristen Sebagai Panggilan Dan Profesi. Bandung: Jurnal Info Media, 2010.

Kristianto, Paulus Lilik. Prinsip Dan Praktek Pendidikan Agama Kristen. Yogayakrta: Andi Offset, 2008.

Kusmana, Ade. "E-Learning Dalam Pembelajaran." LENTERA PENDIDIKAN Vol. 14, N (n.d.): 35-51.

Messakh, Jakob. “Korelasi Kompetensi
Guru PAK SMA Negeri Se-Jakarta Dengan Identitas Sebagai Hamba Tuhan." SIKIP: Jurnal PendidikanAgama Kristen Vol. 1, No (n.d.): 47-59.

Murniati, Erni. “"Microsoft Office Sebagai Penunjang Pembelajaran Daring."' In Webinar Nasional. Batam: STT Real Batam, n.d.

Rofikoh, Nur. "Pengaruh Internet Terhadap Aktivitas Pendidikan." Jurnal Ilmiah (n.d.).

Sarwono. Metode Riset Bidang Desain. Yogayakrta: Andi Offset, 2007.

Sumiyatiningsih, Dien. Mengajar Dengan Kreatif \& Menarik. Yogayakrta: Andi Offset, 2012.

Telaumbanua, Arozatulo. "Peranan Guru Pendidikan Agama Kristen Dalam Membentuk Karakter Siswa." FIDEI: Jurnal Teologi Sistematika dan Praktika 1, no. 2 (2018).

Tjanda, Daniel S. "Impelementasi Pembelajaran Pendidikan Agama Kristen Di Abad 21." SIKIP: Jurnal Pendidikan Agama Kristen Vol. 1, No (n.d.): 1-10.

"Impelementasi Pembelajaran Pendidikan Agama Kristen Di Abad 21." SIKIP: Jurnal Pendidikan Agama Kristen Vol. 1, No (n.d.): 1-10.

"No Title."

Surat Edaran Menteri Pendidikan Dan Kebudayaan Republik Indonesia, Nomor 36962, Hal: Pembelajaran Secara Daring Dan Bekerja Dari Rumah Dalam Rangka Pencegahan Penyebaran Corona Virus Disease (COVID-19)., n.d.

Undang-Undang No. 20 Tahun 2003 Tentang Sistem Pendidikan Nasional, Pasal 31., n.d. 